\title{
Utilizing the Analytic Hierarchy Process to Establish Weighted Values for Evaluating the Stability of Slope Revegetation based on Hydroseeding Applications in South Korea
}

\author{
Sung-Ho Kil ${ }^{1}$, Dong Kun Lee ${ }^{2, *}$, Jun-Hyun Kim ${ }^{1}$, Ming-Han Li ${ }^{1}$ and Galen Newman ${ }^{1}$ \\ Received: 13 August 2015; Accepted: 29 December 2015; Published: 8 January 2016 \\ Academic Editor: Vincenzo Torretta \\ 1 Department of Landscape Architecture and Urban Planning, College of Architecture, \\ Texas A\&M University, College Station, TX 77843-3137, USA; sunghokil@gmail.com (S.-H.K.); \\ JHKim@arch.tamu.edu (J.-H.K.); minghan@tamu.edu (M.-H.L.); gnewman@arch.tamu.edu (G.N.) \\ 2 Department of Landscape Architecture, Graduate School of Environmental Studies, \\ Seoul National University, \#82, 1 Gwanak-ro, Gwanak-gu, Seoul 151-742, Korea \\ * Correspondence: dklee7@snu.ac.kr; Tel.: +82-2-880-4875
}

\begin{abstract}
The aim of this study was to identify the major variables identified as important for considering the stabilization of slope revegetation based on hydroseeding applications and evaluate weights of each variable using the analytic hierarchy process (AHP) with both environmental experts and civil engineers. Twenty-five variables were selected by the experts' survey from a total of 65 from the existing literature, with each variable considered as an important factor for slope stabilization in South Korea. The final results from the AHP method showed that variables associated with the driving force of water resources showed higher values in all expert groups such as rain intensity, seepage water and drainage condition. Other important variables were related to plant growth such as vegetation community, vegetation coverage and quality of soil ameliorant produced in an artificial factory such as tensile strength, permeability coefficient, soil texture and organic matter. The five highest-ranked variables that satisfied both environmental experts and civil engineers were rain intensity, seepage water, slope angle, drainage condition and ground layer. The findings of this research could be helpful for developing a more accurate rating system to evaluate the stability of slope revegetation.
\end{abstract}

Keywords: slope stability; revegetated slope; ecological restoration; stability evaluation

\section{Introduction}

Slope revegetation - the use of vegetation and construction to protect a barren slope damaged by road and building construction-has been widely accepted and used for decades as a means of achieving stability and ecological rehabilitation of rugged terrain. However, revegetated slopes can fail due to various environmental factors such as high rain intensity and steep slopes. Many revegetation applications seek to stabilize barren slopes as a result of urban development and/or road construction. Among the many slope revegetation options available, hydroseeding has been widely applied on large and steep slopes in temperate climates [1-3]. Many slope stability analyses conducted by multi-disciplinary experts show that hydroseeding has become the representative application for damaged slopes in South Korea. Once revegetated, however, slopes can still undergo soil erosion and even natural slope failure (e.g., landslides). Although slope failure can occur as a result of natural geomorphological processes over time [4], revegetated slopes typically fail because most hydroseeding 
applications are involved with the imported soil and vegetation from an entirely new site rather than reinforcing the natural interactions of native soil and vegetation from neighboring environments [5-7].

Studies on slope stability have primarily been conducted from two perspectives: civil and soil conservation engineering. Studies conducted from the civil engineering perspective have mainly evaluated the stability of cut slopes on solid bedrock. These studies mostly evaluated stability in relation to the use of concrete structures to stabilize a damaged slope [8-10] and on numerical and statistical analyses to assess the risks of steep slope failure [11,12]. Studies from the perspective of soil conservation engineering have investigated rock or soil movement by using field monitoring systems [13-15]. They have also involved field surveys and laboratory soil testing [16-19], analytical methods [20], and physically based models for rainfall-induced shallow landslides, including SINMAP [21], dSLAM [22], and SHETRAN [23]. These scientific achievements seek to individually understand the causes and effects of slope failure through interpretation and standardization of particular soil and vegetation variables such as soil porosity, soil organic matter and vegetation cover $[24,25]$. However, many of these approaches have not been directly associated with measuring the stabilization of revegetated slopes.

A multitude of variables are required to analyze the overall stability of revegetated slopes, but integrating all variables of interest together generally results in an ineffective method that is too costly [26]. Not only are scientific approaches needed to investigate slope failure, but simple methods are also required to evaluate stability of revegetated slopes. One of the more popular methods is a sociological approach based on the Multi-Criteria Decision Making (MCDM) approach, a valuable method in making important decisions that cannot be easily decided [27].

MCDM methods can be broadly classified into the following four types: Analytical Hierarchy Process (AHP), Novel Approach to Imprecise Assessment and Decision Environments (NAIADE), Multi-Attribute Utility Theory (MAUT), and Multi-Objective Programming (MOP) [28]. Among these, AHP — a standard method to calculate weights—has been widely used in the decision-making approaches of fields such as landscape/architectural design, urban planning and the evaluation of strategic policies [29-33]. Introduced by Saaty [34], AHP is used to derive ratio scales from both discrete and continuous paired comparisons [35]. It is a reliable tool to reinforce logical and reasonable decision-making processes, and determine the importance of criteria and sub-criteria [27,36]. Analyzing the relative weights of variables by AHP can help to evaluate the overall stability of slope revegetation.

The knowledge gained from this method could then be used to develop a facilitated rating system such as that of rockfall hazard [37-39]. Furthermore, a comprehensive review of the stability of slope revegetation has not yet been conducted in South Korea. This study focused on the selection of appropriate variables through the use of AHP to represent numerous variables for slope failure and soil erosion of revegetation and evaluating whether the weighted values for the selected variables differed between environmental experts and civil engineers.

\section{Methods}

\subsection{Variable Selection and Survey Method}

The process of variable selection was conducted in two steps: (1) collecting appropriate variables from the literature, and (2) extracting major variables from this list using an expert survey (Figure 1). In the first step, the variables relevant to stabilization failure of slope revegetation were collected from previous studies in multiple fields including civil engineering, soil erosion control engineering, and slope revegetation. Variables with overlapping meanings or repeated occurrences were integrated into a single category. For example, slope inclination, inclination, and slope angle have similar meanings. Therefore, "slope angle" was selected as the variable. As shown in Table 1, a total of 65 variables were collected from previous literature. Brainstorming with expert groups via emails helped to both select and label these variables. The 65 variables also included a short description to explain the content (See Appendix Table A1). Based on the review of research studying weights of factors affecting 
slope stability [40], the 65 variables were divided into seven main categories: topography, geography, climate, soil physics, soil chemistry, vegetation and construction. The numbers of variables for the seven categories by the experts were as follows: 11 for topography, eight for geology, three for climate, 12 for soil physics, 11 for soil chemistry, 13 for vegetation, and seven for construction.

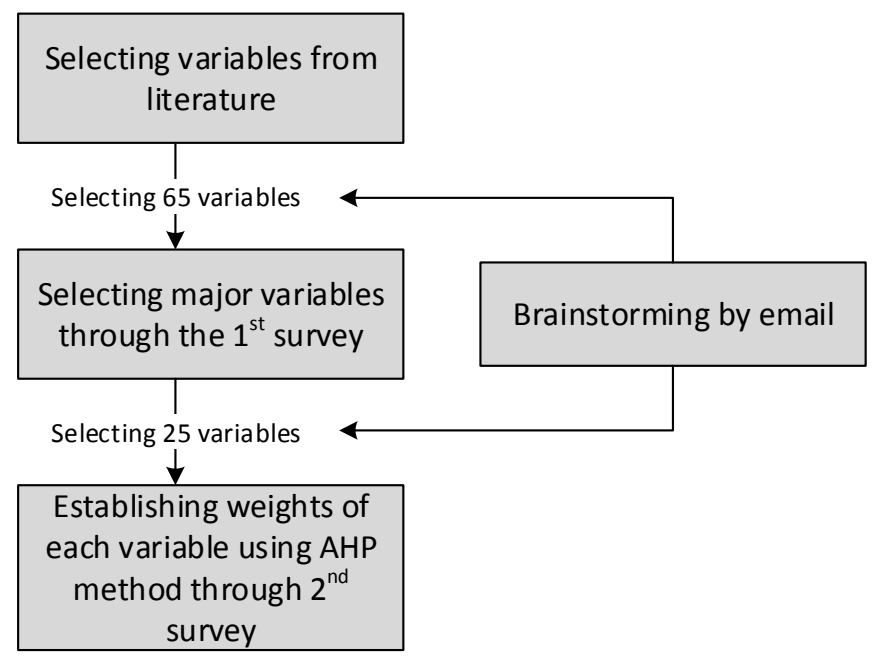

Figure 1. Variable and data collection process with multiple surveys.

Table 1. Sixty-five variables related to slope stability from the existing literature.

\begin{tabular}{|c|c|c|}
\hline Categories & Major Variables & References \\
\hline Topography & $\begin{array}{c}\text { Slope angle, Slope height, Slope location, Slope type, Slope length, } \\
\text { Altitude, Aspect, Curvature, Catchment basin, Stream power } \\
\text { index (SPI), Topographic wet index (TWI) }\end{array}$ & [39-47] \\
\hline Geology & $\begin{array}{l}\text { Ground layer, Rock type, Joint condition, } \\
\text { Joint orientation, Weathering characteristics, } \\
\text { Weathered condition, Tension crack, Seepage water }\end{array}$ & {$[39-43,48-50]$} \\
\hline Climate & Rain intensity, Daily rainfall, Accumulated rainfall & {$[39,40,44,47,51]$} \\
\hline Soil physics & $\begin{array}{l}\text { Porosity, Bulk density, Gravel contents, Grain size, } \\
\text { Soil hardness, Water content, Soil texture, Permeability coefficient, } \\
\text { Tensile strength, Shear strength, Specific gravity }\end{array}$ & {$[22,40,43,46,47,51-58]$} \\
\hline Soil chemistry & $\begin{array}{c}\text { Soil acidity }(\mathrm{pH}) \text {, Cation Exchange Capacity (CEC), Electronic } \\
\text { conductivity (EC), Available phosphate, Soil organic matter, } \\
\mathrm{C} / \mathrm{N} \text {, Salt concentration, Total nitrogen (T-N), } \\
\text { Exchangeable calcium, Exchangeable magnesium, } \\
\text { Exchangeable potassium, Exchangeable sodium }\end{array}$ & {$[43,55,59]$} \\
\hline Vegetation & $\begin{array}{l}\text { Forest stand, Tree height, Species diversity, } \\
\text { Dominant plant species, Number of trees, } \\
\text { Number of herbs, Vegetation coverage, Vegetation density, } \\
\text { Germination percentage, Vegetation community, } \\
\text { Timber age class, Timber diameter class, Root reinforcement }\end{array}$ & {$[40,46,54,55,58,60-62]$} \\
\hline Construction & $\begin{array}{l}\text { Soil depth, Land use, Drainage system, Elapsed year, Scale of } \\
\text { failure, Collapse history, Reinforced facility for slope protection }\end{array}$ & {$[39,45,46,57,62]$} \\
\hline
\end{tabular}

The second step was to establish the key variables for slope stability by hydroseeding-based revegetation. The number of the key variables related to stabilizing slopes using the hydroseeding method was reduced to 25 of the total 65 variables. These 25 variables were selected using a survey distributed to experts based on the multiple response method, which allowed respondents to choose two or more answers to a question. 
As shown in Table 2, the numbers of variables for the seven categories eventually utilized for the AHP analysis were as follows: five for topography, two for geology, two for climate, six for soil physics, three for soil chemistry, four for vegetation, and three for construction.

Table 2. Twenty-five variables extracted for Analytical Hierarchy Process (AHP) analysis from the first survey.

\begin{tabular}{cr}
\hline Categories & Extracted Variables \\
\hline Topography & Slope angle, Aspect, Slope length, Slope height, Slope type \\
\hline Geography & Ground condition, Seepage water \\
\hline Climate & Rain intensity, Accumulated rainfall \\
\hline Soil physics & Porosity, Soil hardness, Water contents, Soil texture, Tensile strength, Hydraulic conductivity \\
\hline Soil chemistry & Soil acidity $(\mathrm{pH})$, Salt concentration, Organic Matter \\
\hline Vegetation & Vegetation community, Vegetation coverage rate, Number of trees, Number of herbs \\
\hline Construction & Elapsed year, Drainage condition, Soil depth \\
\hline
\end{tabular}

Variables dealing with structural stability were either excluded or integrated via a survey of experts and brainstorming because the evaluation of structural stability is generally performed before slope revegetation. Revegetating construction is performed after assessing stability through geotechnical investigation by civil engineers who review applicable techniques of revegetation to minimize impediment of structural stability after revegetating.

Participants in the brainstorming process had wide experience in regards to slope revegetation: one soil expert, one environmental planner and one vegetation expert who served in their professional fields for 10 years or more, two officers in charge of road construction in National Highway Planning and Construction Division in the Ministry of Land, Infrastructure and Transport (MOLIT) in the South Korean government and two civil engineers who have worked on a considerable number of construction projects. During the brainstorming prior to the survey, continual correspondence occurred back and forth in order to select final variables. Respondents for the survey were selected from revegetation-experienced experts who had published one or more articles on the subject, had hands-on experience in revegetation, or had previously led a revegetation project (Table 3). Most had more than 10 years of experience in their respective fields. There were fewer civil engineers among the respondents. Most of the respondents were landscape architects or environmental engineers because they usually deal with the processes of slope vegetation. In addition, many of them were also in academia in the field of ecological restoration and/or civil engineering, were employees in high-ranked companies having a considerable amount of annual turnover in the field of construction and design of slope revegetation, or were in the department of road construction in National Highway Planning and Construction Division in MOLIT in the South Korean government.

Table 3. Classification of respondents

\begin{tabular}{cccc}
\hline & Classification & First Survey & Second Survey \\
\hline \multirow{2}{*}{ Major } & Environment & 28 & 23 \\
& Civil engineering & 9 & 15 \\
Career & Above 10 years & 25 & 27 \\
& 6 to 9 years & 10 & 8 \\
& Below 5 years & 2 & 3 \\
Organization & Educational institution & 10 & 11 \\
& Government & 3 & 10 \\
& Private company & 24 & 17 \\
Total & & 37 & 38 \\
\hline
\end{tabular}

A questionnaire survey based on the multiple response method was distributed during the period of 1-13 April 2013 to the experts through interview and e-mail. The final 25 variables were suggested 
by more than half the respondents were first identified from the responses of 37 experts. The weights of the major variables were set by 38 experts using AHP through the second survey. For each variable, a pairwise comparison matrix was created to calculate its weighted value by AHP.

\subsection{AHP Analysis}

The AHP method is a mathematical method for analyzing and organizing complex decisions using ratio scale measurement [32]. It has been applied in studies with small sample sizes to solicit and determine the hierarchical analysis, typically based on experts' opinion. This study used a limited number of experts with thorough experience, but few in South Korea have had extensive experience with slope revegetation. Several studies reported findings from AHP with small numbers of experts: five respondents [63], five participants [64], seven participants [65], 18 participants [66] and 25 respondents [67].

The evaluation method of AHP requires a small number of key variables that jointly explain much of the variance in the stability of revegetated slopes $[68,69]$. The variables should be weighted relatively to how important each is for the structural stability of a particular revegetated slope [70]. Ideally, there should be a broad consensus among the experts on variables that determine the stability of a revegetated slope.

The AHP analysis involved the following steps: (1) identifying environmental experts and civil engineers; (2) calculating local and global weights for each category and variable through geometric average for acceptable consistency ratio related to a value less than or equal to 0.1 for each group; (3) calculating integrated weights by considering both groups.

In the first step, the experts consisted of two groups: environmental experts and civil engineers. The former included landscape architects, environmental engineers, and forest specialists. The latter included geotechnical and professional engineers for civil engineering structures and road development.

In the second step, weights were estimated for the variables obtained from the initial survey. A scale of relative importance based on a pairwise comparison of questionnaires is shown in Table 4 . The survey consisted of pairwise comparisons of the individual variables on the same hierarchy within a group of variables. Each variable also included a short description to explain the content. Experts selected a value on the scale 1-9 proposed by Saaty and Vargas [71]. There were 60 pairwise comparisons determined by the experts in the survey.

The weights were classified into two types: local weights and global weights. The value of a local weight was the AHP result of each category or variable. The sum of local weights of the total categories or variables on the same hierarchy was 1.00. The value of global weight equaled the value of the local weight within each category multiplied by the value of local weight within each variable. The sum of global weights was also 1.00. For example, the value of the global weight for slope angle was equal to the local weight of the topography category multiplied by the local weight of the slope angle variable. The ranking was arranged according to the order of the global weight.

Table 4. Pairwise comparison scale for AHP preferences [34].

\begin{tabular}{ccc}
\hline Intensity of importance & Definition & Explanation \\
\hline 1 & Equal importance & $\begin{array}{c}\text { Two categories or variables contribute } \\
\text { equally to the objective }\end{array}$ \\
\hline 3 & Moderate importance & $\begin{array}{c}\text { Experience and judgment slightly favor } \\
\text { one category or variable over another }\end{array}$ \\
\hline 5 & Strong importance & $\begin{array}{c}\text { Experience and judgment strongly favor } \\
\text { one category or variable over another }\end{array}$ \\
\hline 7 & Very strong or demonstrated & $\begin{array}{c}\text { An category or variable is favored very } \\
\text { importance }\end{array}$ \\
\hline
\end{tabular}


Table 4. Cont.

\begin{tabular}{ccc}
\hline Intensity of importance & Definition & Explanation \\
\hline 9 & Extreme importance & $\begin{array}{c}\text { The evidence favoring one category or } \\
\text { variable over another is of the highest } \\
\text { possible order of affirmation }\end{array}$ \\
\hline Reciprocals of above & $\begin{array}{c}\text { If activity } i \text { has one of the above nonzero } \\
\text { numbers assigned to it when compared } \\
\text { with activity } j \text {, then } j \text { has the reciprocal } \\
\text { value when compared with } i\end{array}$ & A reasonable assumption \\
Rational & Ratios arising from the scale & $\begin{array}{c}\text { If consistency were to be forced by } \\
\text { obtaining } n \text { numerical values to span } \\
\text { the matrix }\end{array}$ \\
\hline
\end{tabular}

The AHP verifies a consistency ratio (CR) to measure the consistency of experts' judgments arranged in pairwise comparisons from the result of survey. A CR value above 0.10 indicate that the respondent is considered to give reasonable answers [71]. In addition to the CR, the consistency index (CI) and random index (RI) were measured. The CI evaluates the consistency of matrix of order $n$ to determine how much inconsistency is in a matrix. RI is the average CI depending on the order $n$ of the matrix. The RI generally utilize the value given by Saaty [34] as following Table $5[27,33,64]$. The formulas for $\mathrm{CR}$ and $\mathrm{CI}$ are shown below:

$$
\begin{gathered}
\mathrm{CR}=\frac{C I}{R I} \\
\mathrm{CI}=\frac{\left(\lambda_{\max }-n\right)}{(n-1)}
\end{gathered}
$$

where $\lambda_{\max }$ is the maximum eigenvalue of the matrix, $n$ is the matrix size, and RI is the average CI for a number of randomly generated matrices according to Table 5 . For each variable, the reasons for why the two groups may have differed were considered.

Table 5. Random consistency index for corresponding number of categories and variables [34].

\begin{tabular}{cccccccc}
\hline $\mathbf{n}$ & $\mathbf{1}$ & $\mathbf{2}$ & $\mathbf{3}$ & $\mathbf{4}$ & $\mathbf{5}$ & $\mathbf{6}$ & $\mathbf{7}$ \\
\hline $\mathrm{RI}$ & 0 & 0 & 0.58 & 0.9 & 1.12 & 1.24 & 1.32 \\
\hline \multicolumn{7}{c}{ RI, Random index. }
\end{tabular}

In the third step, the integrated weights for categories or variables satisfying the $C R$ value above 0.10 were calculated by an AHP analysis including the result of pairwise comparisons selected by all experts based on results from the second step.

\section{Results}

\subsection{Tendencies for Weighted Factors}

\subsubsection{Weighted Values of Environmental Experts}

Environmental experts weighted the variables as shown in Table 6. Compared with local weights in each category, the values for soil physics $(0.183)$ and vegetation $(0.176)$ indicated relatively higher levels of importance. Among the variables for topography, the value for slope angle (0.509) showed the highest importance. The variable of the greatest importance in geography and climate category were seepage water (0.576) and rain intensity (0.769), respectively. The values for tensile strength (0.210) and permeability coefficient $(0.218)$ were higher than those for other variables in the soil physics category. 
Salt concentration (0.458) was the main soil chemistry variable. The values for vegetation community (0.277) and vegetation coverage rate $(0.388)$ were higher than those for other variables in the vegetation category. The variable of drainage condition (0.613) showed the highest value among the variables in the construction category.

Table 6. Weighted values and rankings considered by environmental experts.

\begin{tabular}{|c|c|c|c|c|c|}
\hline Categories & Local Weight & Variables & Local Weight & Global Weight & Rank \\
\hline \multirow{5}{*}{ Topography } & \multirow{5}{*}{0.142} & Slope angle & 0.509 & 0.0723 & 3 \\
\hline & & Aspect & 0.099 & 0.0141 & 25 \\
\hline & & Slope length & 0.109 & 0.0155 & 24 \\
\hline & & Slope height & 0.142 & 0.0202 & 21 \\
\hline & & Slope type & 0.141 & 0.0200 & 22 \\
\hline \multirow{2}{*}{ Geography } & \multirow{2}{*}{0.113} & Ground layer & 0.424 & 0.0479 & 7 \\
\hline & & Seepage water & 0.576 & 0.0651 & 5 \\
\hline \multirow[b]{2}{*}{ Climate } & \multirow[b]{2}{*}{0.152} & Rain intensity & 0.769 & 0.1169 & 1 \\
\hline & & $\begin{array}{l}\text { Accumulated } \\
\text { rainfall }\end{array}$ & 0.231 & 0.0351 & 12 \\
\hline \multirow{6}{*}{ Soil physics } & \multirow{6}{*}{0.183} & Porosity & 0.129 & 0.0236 & 18 \\
\hline & & Soil hardness & 0.128 & 0.0234 & 19 \\
\hline & & Water content & 0.121 & 0.0221 & 20 \\
\hline & & Soil texture & 0.195 & 0.0357 & 11 \\
\hline & & Tensile strength & 0.210 & 0.0384 & 10 \\
\hline & & $\begin{array}{c}\text { Permeability } \\
\text { coefficient }\end{array}$ & 0.218 & 0.0399 & 8 \\
\hline \multirow{3}{*}{$\begin{array}{c}\text { Soil } \\
\text { chemistry }\end{array}$} & \multirow{3}{*}{0.087} & Soil acidity & 0.222 & 0.0193 & 23 \\
\hline & & $\begin{array}{c}\text { Salt } \\
\text { concentration }\end{array}$ & 0.458 & 0.0398 & 9 \\
\hline & & Organic matter & 0.320 & 0.0278 & 15 \\
\hline \multirow{4}{*}{ Vegetation } & \multirow{4}{*}{0.176} & $\begin{array}{l}\text { Vegetation } \\
\text { community }\end{array}$ & 0.277 & 0.0488 & 6 \\
\hline & & $\begin{array}{l}\text { Vegetation } \\
\text { coverage rate }\end{array}$ & 0.388 & 0.0683 & 4 \\
\hline & & $\begin{array}{c}\text { Number of } \\
\text { trees }\end{array}$ & 0.146 & 0.0257 & 17 \\
\hline & & $\begin{array}{c}\text { Number of } \\
\text { herbs }\end{array}$ & 0.189 & 0.0333 & 13 \\
\hline \multirow{3}{*}{ Construction } & \multirow{3}{*}{0.147} & Elapsed year & 0.199 & 0.0293 & 14 \\
\hline & & $\begin{array}{l}\text { Drainage } \\
\text { condition }\end{array}$ & 0.613 & 0.0901 & 2 \\
\hline & & Soil depth & 0.188 & 0.0276 & 16 \\
\hline
\end{tabular}

The variables with the five highest-ranked final weights among global weights were rain intensity (0.1169), drainage condition (0.0901), slope angle (0.0723), vegetation coverage rate $(0.0683)$, and seepage water $(0.0651)$.

\subsubsection{Weighted Values of Civil Engineers}

Civil engineers weighted the variables as shown in Table 7. Compared with local weights in categories, the values for topography (0.172) and geography (0.219) indicated relatively higher importance. As was the case for the environmental experts, the value for slope angle $(0.374)$ showed the highest importance among the variables in the topography category. The values for seepage water (0.615) and accumulated rainfall (0.520) indicated that they were the variables of the greatest importance for the categories of geography and climate, respectively. The values for tensile strength (0.262), soil texture $(0.208)$, and water content $(0.160)$ were higher than those for other variables in 
the soil physics category. Organic matter (0.443) was the main soil chemistry variable. The values for vegetation community $(0.356)$ and vegetation coverage rate $(0.237)$ were higher than those for the other variables in the vegetation category. The elapsed year $(0.360)$ and drainage condition (0.467) were the main variables in the construction category.

Table 7. Weighted values and rankings considered by civil engineers.

\begin{tabular}{|c|c|c|c|c|c|}
\hline Categories & Local Weight & Variables & Local Weight & Global Weight & Rank \\
\hline \multirow{5}{*}{ Topography } & \multirow{5}{*}{0.172} & Slope angle & 0.374 & 0.0643 & 5 \\
\hline & & Aspect & 0.110 & 0.0189 & 22 \\
\hline & & Slope length & 0.112 & 0.0193 & 21 \\
\hline & & Slope height & 0.191 & 0.0329 & 13 \\
\hline & & Slope type & 0.213 & 0.0366 & 9 \\
\hline \multirow{2}{*}{ Geography } & \multirow{2}{*}{0.219} & Ground layer & 0.385 & 0.0843 & 2 \\
\hline & & Seepage water & 0.615 & 0.1347 & 1 \\
\hline \multirow[b]{2}{*}{ Climate } & \multirow[b]{2}{*}{0.147} & Rain intensity & 0.480 & 0.0706 & 4 \\
\hline & & $\begin{array}{l}\text { Accumulated } \\
\text { rainfall }\end{array}$ & 0.520 & 0.0764 & 3 \\
\hline \multirow{6}{*}{ Soil physics } & \multirow{6}{*}{0.129} & Porosity & 0.122 & 0.0157 & 24 \\
\hline & & Soil hardness & 0.089 & 0.0115 & 25 \\
\hline & & Water content & 0.160 & 0.0206 & 19 \\
\hline & & Soil texture & 0.208 & 0.0268 & 17 \\
\hline & & Tensile strength & 0.262 & 0.0338 & 11 \\
\hline & & $\begin{array}{c}\text { Permeability } \\
\text { coefficient }\end{array}$ & 0.158 & 0.0204 & 20 \\
\hline \multirow{3}{*}{$\begin{array}{c}\text { Soil } \\
\text { chemistry }\end{array}$} & \multirow{3}{*}{0.087} & Soil acidity & 0.316 & 0.0275 & 16 \\
\hline & & $\begin{array}{c}\text { Salt } \\
\text { concentration }\end{array}$ & 0.241 & 0.0210 & 18 \\
\hline & & Organic matter & 0.443 & 0.0385 & 8 \\
\hline \multirow{4}{*}{ Vegetation } & \multirow{4}{*}{0.154} & $\begin{array}{l}\text { Vegetation } \\
\text { community }\end{array}$ & 0.356 & 0.0548 & 6 \\
\hline & & $\begin{array}{l}\text { Vegetation } \\
\text { coverage rate }\end{array}$ & 0.237 & 0.0365 & 10 \\
\hline & & Number of trees & 0.199 & 0.0306 & 15 \\
\hline & & Number of herbs & 0.208 & 0.0320 & 14 \\
\hline \multirow{3}{*}{ Construction } & \multirow{3}{*}{0.092} & Elapsed year & 0.360 & 0.0331 & 12 \\
\hline & & $\begin{array}{l}\text { Drainage } \\
\text { condition }\end{array}$ & 0.467 & 0.0430 & 7 \\
\hline & & Soil depth & 0.173 & 0.0159 & 23 \\
\hline
\end{tabular}

The variables with the five highest-ranked weights among global weights were seepage water (0.1347), ground layer (0.0843), accumulated rainfall (0.0764), rain intensity (0.0706), and slope angle (0.0644). Geographical and climatic variables dominated the global weights. In addition, variables related to water resources ranked high among the global weights.

\subsection{Weighted Values of Comprehensive Experts.}

Both groups of experts weighted the variables as shown in Table 8. Among the categories, the local weights of most categories ranged from 0.150 to 0.170 , except for soil chemistry (0.088) and construction (0.125). As the results of the environmental experts and civil engineers, the value for slope angle (0.465) showed the highest importance among the variables in topography category. The values for seepage water (0.591) and rain intensity (0.668) indicated that they were the variables of the greatest importance for the categories of geography and climate, respectively. The values for tensile strength $(0.232)$ and soil texture $(0.202)$ were higher than those for the other variables in soil physics category. Organic matter (0.375) and salt concentration (0.361) were the main variables in soil chemistry category. 
The values for vegetation community $(0.305)$ and vegetation coverage rate $(0.333)$ were higher than those for the other variables in the vegetation category. The drainage condition (0.564) was the main variable in the construction category.

Table 8. Weighted values and rankings considered by both groups of experts.

\begin{tabular}{|c|c|c|c|c|c|}
\hline Categories & Local Weight & Variables & Local Weight & Global Weight & Rank \\
\hline \multirow{5}{*}{ Topography } & \multirow{5}{*}{0.154} & Slope angle & 0.465 & 0.0716 & 3 \\
\hline & & Aspect & 0.104 & 0.0160 & 25 \\
\hline & & Slope length & 0.111 & 0.0171 & 24 \\
\hline & & Slope height & 0.158 & 0.0243 & 18 \\
\hline & & Slope type & 0.162 & 0.0249 & 17 \\
\hline \multirow{2}{*}{ Geography } & \multirow{2}{*}{0.147} & Ground layer & 0.409 & 0.0601 & 5 \\
\hline & & Seepage water & 0.591 & 0.0869 & 2 \\
\hline \multirow[b]{2}{*}{ Climate } & \multirow[b]{2}{*}{0.152} & Rain intensity & 0.668 & 0.1015 & 1 \\
\hline & & $\begin{array}{l}\text { Accumulated } \\
\text { rainfall }\end{array}$ & 0.332 & 0.0505 & 8 \\
\hline \multirow{6}{*}{ Soil physics } & \multirow{6}{*}{0.163} & Porosity & 0.127 & 0.0207 & 22 \\
\hline & & Soil hardness & 0.111 & 0.0181 & 23 \\
\hline & & Water content & 0.137 & 0.0223 & 21 \\
\hline & & Soil texture & 0.202 & 0.0329 & 12 \\
\hline & & Tensile strength & 0.232 & 0.0378 & 9 \\
\hline & & $\begin{array}{c}\text { Permeability } \\
\text { coefficient }\end{array}$ & 0.191 & 0.0311 & 14 \\
\hline \multirow{3}{*}{$\begin{array}{c}\text { Soil } \\
\text { chemistry }\end{array}$} & \multirow{3}{*}{0.088} & Soil acidity & 0.264 & 0.0232 & 19 \\
\hline & & $\begin{array}{c}\text { Salt } \\
\text { concentration }\end{array}$ & 0.361 & 0.0318 & 13 \\
\hline & & Organic matter & 0.375 & 0.0330 & 11 \\
\hline \multirow{4}{*}{ Vegetation } & \multirow{4}{*}{0.170} & $\begin{array}{l}\text { Vegetation } \\
\text { community }\end{array}$ & 0.305 & 0.0519 & 7 \\
\hline & & $\begin{array}{l}\text { Vegetation } \\
\text { coverage rate }\end{array}$ & 0.333 & 0.0566 & 6 \\
\hline & & Number of trees & 0.164 & 0.0279 & 16 \\
\hline & & Number of herbs & 0.198 & 0.0337 & 10 \\
\hline \multirow{3}{*}{ Construction } & \multirow{3}{*}{0.125} & Elapsed year & 0.250 & 0.0313 & 15 \\
\hline & & $\begin{array}{l}\text { Drainage } \\
\text { condition }\end{array}$ & 0.564 & 0.0705 & 4 \\
\hline & & Soil depth & 0.185 & 0.0231 & 20 \\
\hline
\end{tabular}

The variables with the five highest-ranked weights were rain intensity (0.1015), seepage water (0.0869), slope angle (0.0716), drainage condition (0.0705), and ground layer (0.0601). The global weights were similar to those of the two groups analyzed independently.

\section{Discussion}

\subsection{Variable Extraction}

The 25 selected variables could play a major role in stability evaluation of a revegetated slope. These variables could be used to create a rating system, such as the slope mass rating (SMR) system proposed by Romana et al. [72], and to integrate the dynamics of major variables for the stability of slope revegetation. The main variables selected for this research could be effectively used to substantially reduce time and costs. 


\subsection{Comparison of Weighted Values between Environmental Experts and Civil Engineers}

Environmental experts and civil engineers had different opinions on some variables (Figure 2). For the categories, environmental experts indicated soil physics $(0.183)$ and vegetation $(0.176)$ as the more important categories, whereas civil engineers considered topography (0.172) and geography $(0.219)$ as more important. Although structural stability is generally checked to revegetate a damaged slope, civil engineers considered topographical and geographical variables as key values. Environmental experts might be interested in how to grow healthy plants and form soil profiles. Weighted values considered by comprehensive experts focused on soil physics (0.163) and vegetation (0.170). The value for vegetation was higher than that for soil. Among the three groups, the value for soil chemistry was lowest for environmental experts, followed by civil engineers and comprehensive experts.

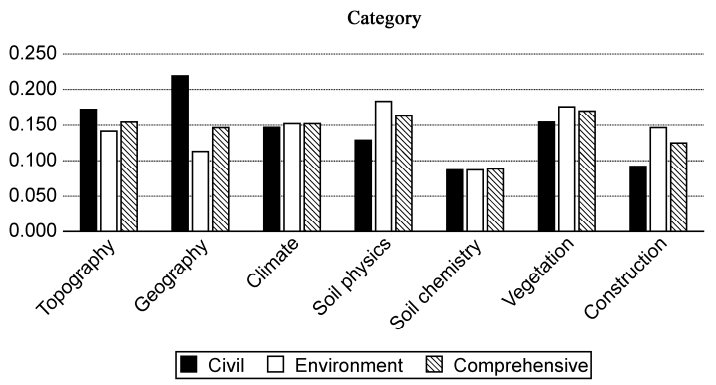

(a)

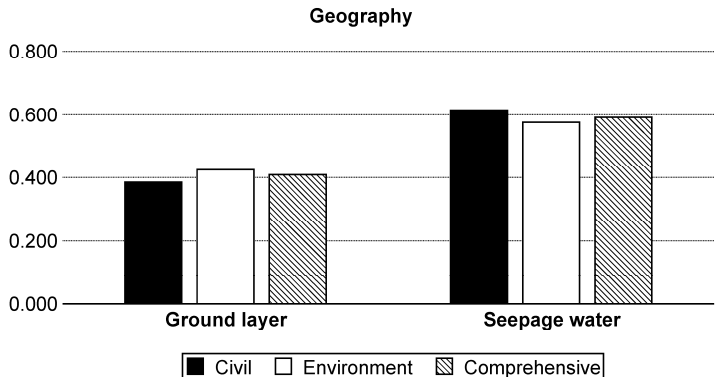

(c)

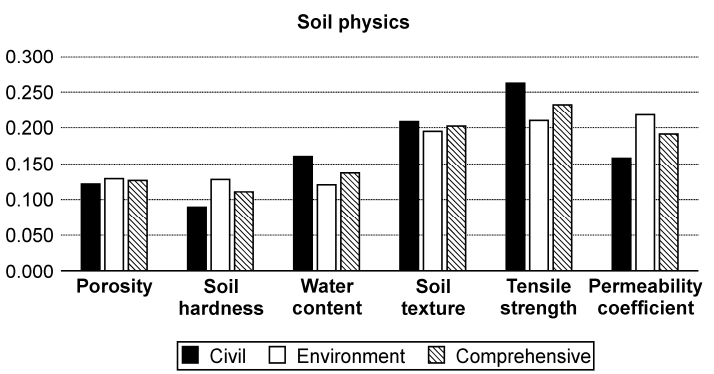

(e)

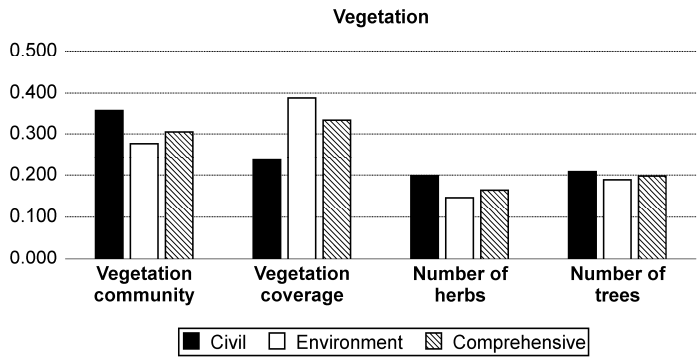

(g)

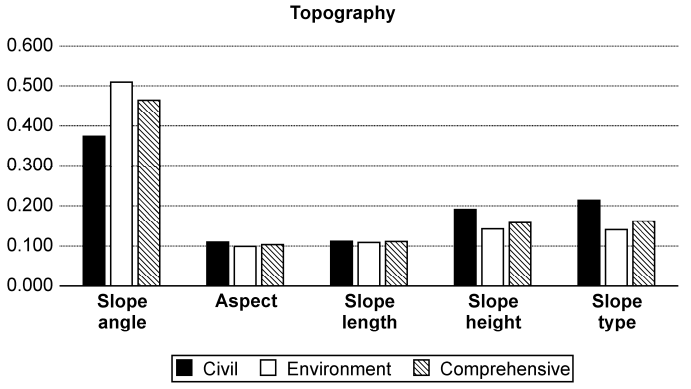

(b)

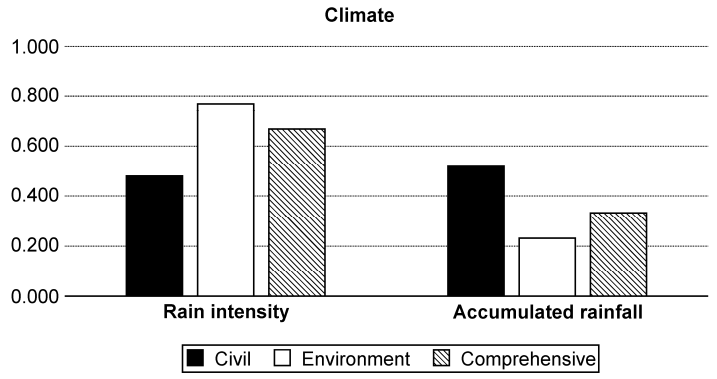

(d)
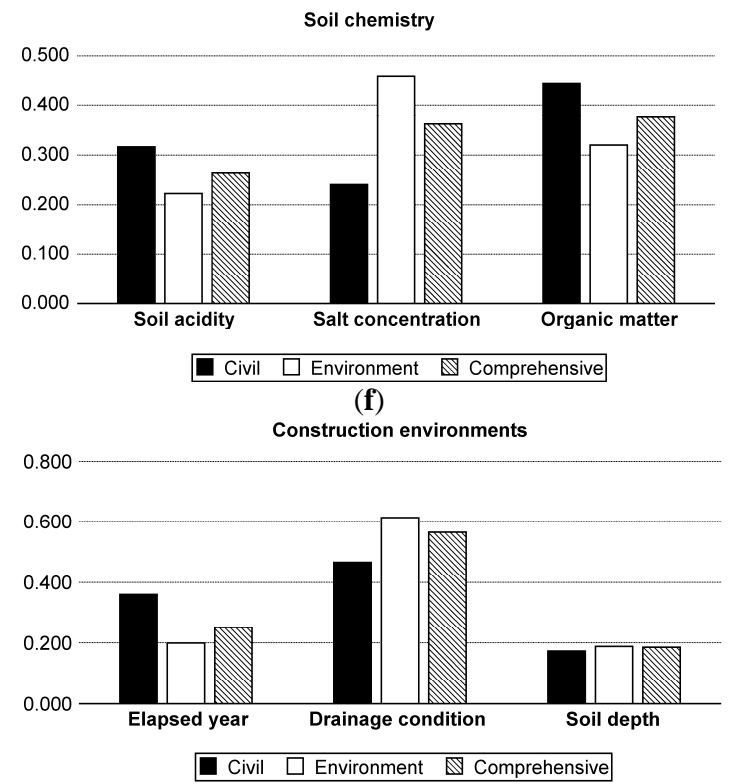

(h)

Figure 2. Local weights for each category and variable, (a) values of each category, (b-h) values of each variable among three groups: civil engineers, environmental experts and comprehensive experts. 
For variables, the slope angle, slope length, and slope type were more important than other topographical variables in all three groups. The value for slope angle had the highest score. Slope angle is one of the major variables in surface stability because it has a direct effect on how soil particles respond to erosional strength [73]. A steep slope is a sufficient condition that causes failure and a factor that makes it difficult to establish vegetation coverage [74]. This, presumably, is why slope angle was selected by the three groups as a main variable.

Of the two geographical variables, seepage water was more critical than ground layer in all three groups. Seepage affects the stability of slope revegetation. Seepage flow often ensues when the pores between soils or the holes of a crack in a bedrock become saturated with water and intersect with a restrictive layer-any soil stratum or layer with low permeability, including unfractured bedrock, which restricts the vertical movement of water [73,75].

Tensile strength, permeability coefficient, and soil texture were the main identified variables among the six variables for soil physics. Soil texture is one of the fundamental variables of soil physics. Soil containing a large volume of sand has a high level of permeability but low nutrition holding capacity [76]. The nutrition holding capacity affects soil organic matter. Soil that contains sufficient soil organic matter forms a stable granular structure, in which water conducts more rapidly than in an unstable structure easily damaged by humidity [77]. These three variables in soil physics category may have been selected because these characteristics would be expected to be considered by experts.

The value for soil chemistry was the lowest among the categories. The chemical properties of soil measure the nutrient conditions necessary for plant growth [76]. The selected variables in this study were soil acidity $(\mathrm{pH})$, soil organic matter, and salt concentration.

Vegetation community and vegetation coverage were the key vegetation variables. Regardless of the number of vegetation species, experts focused on vegetation community with high-coverage plants and high species diversity. Vegetation coverage is, apparently, a good protector of soil particle detachment because it intercepts raindrops [74,78,79]. However, variables in root zone such as tensile root force and root shear strength should also be considered to develop evaluation of slope stability with numerical modeling and stability analyses by considering vegetation influencing the factor of safety, defined as the ratio between resistive and driving forces by gravity [80-82].

Rain intensity, seepage water, and drainage condition affecting water resources generally indicated high global-weight values in all groups. Among experts, the erosion and failure caused by the driving force of water resources was recognized from important studies. The second key issue was the importance of variables related to plant growth. The representative variables were slope angle, vegetation community, and vegetation coverage, which showed somewhat high values in all three groups. Among experts, vegetation variables were considered to play an important role in erosion control and failure protection. The third was the quality of the soil ameliorant input to slope revegetation. The tensile strength, permeability coefficient, soil texture, and organic matter were relatively critical variables. These variables could become important factors when they reach certain levels in soil produced in a special factory for slope revegetation.

Interestingly, several experts considered slope length and aspect as less important variables. Solar radiation is as crucial as a microclimate factor in a cut slope [74]. The aspect in a cut slope determines the incident angle of solar radiation $[83,84]$. Aspect is closely related to the sunshine duration of mountainous slopes. In addition, the longer the slope length, the less the pace of vegetation coverage and the longer the time required to stabilization of revegetation $[85,86]$. Therefore, these variables could be considered to stabilize a damaged slope sufficiently despite their lower values.

These identified variables may be applied as a model or framework for variable selection in various future studies. Furthermore, various analyses such as correlation analysis and numerical analysis, conducted through measurements of each variable in on-the-spot surveys, will be helpful to understand the stability of slope revegetation and to develop a detailed rating system such as that of rockfall hazard [37-39]. 


\section{Conclusions}

Every case study to investigate slope stability needs to be analyzed and resolved independently through numerical and statistical methods with on-the-spot investigation. A single case study can be helpful to understand cause and effect of slope failure though detailed analysis. However, when many provisional diagnoses of slope stability are needed, single case studies can be costly and time consuming. In order to overcome these limitations, simple and easy-to-use methods such as Slope Mass Rating (SMR) [87] and the Rockfall Hazard Rating System (RHRS) [37-39] have been developed for evaluation of slope stability. However, a clear evaluation method related to slope revegetation has not yet been developed. This study aimed to investigate weights of major variables to develop a rating system for stability of slope revegetation using various experts. The selected variables, identified via an expert survey, have direct and indirect effects on the stability of a revegetated slope. In our results, variables related to water resources, plant growth, and soil quality were highly ranked. These were rain intensity, seepage water, drainage condition, slope angle, vegetation community, vegetation coverage, tensile strength, permeability coefficient, soil texture, and organic matter. The five highest-ranked variables that satisfied both groups were rain intensity, seepage water, slope angle, drainage condition, and ground layer. Because ground layer was highly ranked by civil engineers, it was eventually selected.

This study did not include some of the potential variables for diastrophisms such as earthquakes, and were limited to hydroseeding applications of slope revegetation. Therefore, these results might be restricted to studies related to slope failure issues such as landslide and large-scale soil erosion. Furthermore, the use of these variables should be accompanied by scientific results including numerical and statistical analyses to develop the rating system for evaluating the stability of slope revegetation.

Acknowledgments: This research was supported by "Development of Climate Change Adaptation and Management Technique, and Supportive System (Korea Ministry of Environment, Project number: 416-111-014)" and "Development of Economic Assessment Technique for Climate Change Impact and Adaptation Considering Uncertainties (Korea Ministry of Environment, Project number: 2014001310010)". The funding organization had no involvement in study design; collection, analysis and interpretation of data; the writing of the report; or the decision to submit the article for publication.

Author Contributions: Sung-Ho Kil designed the research, analyzed data, and led to write this manuscript; Dong-Kun Lee made a substantial contribution to the interpretation of the results; Jun-Hyun Kim reviewed the literature and contributed to improving the discussion about AHP analysis. Ming-Han Li and Galen Newman edited the manuscript. All authors read and approved the final manuscript.

Conflicts of Interest: The authors declare no conflict of interest.

\section{Appendix}

Table A1. Variable explanation used for this study.

\begin{tabular}{|c|c|c|}
\hline Topography & Unit & Explanation \\
\hline Slope angle & $\circ$ & Angle of inclination \\
\hline Slope height & $\mathrm{m}$ & $\begin{array}{l}\text { Straight-line distance from the center of the bottom of a slope to } \\
\text { the top of adjacent forests }\end{array}$ \\
\hline Slope location & - & Location of a revegetated slope \\
\hline Slope type & - & $\begin{array}{l}\text { Various types of curved or straightened slope after constructing (Straight (口), } \\
\text { Concave (凹 ), Convex (凸 ), Compound (凹凸 )) }\end{array}$ \\
\hline Slope width & $\mathrm{m}$ & Straight-line distance of lower section in a slope \\
\hline Altitude & $\mathrm{m}$ & Altitude above sea level \\
\hline Aspect & o & Compass direction facing of a slope \\
\hline Curvature & & Torsion degree of a curved-slope \\
\hline Catchment basin & $\mathrm{m}^{2}$ & An area of land having capacity of water resources \\
\hline $\begin{array}{l}\text { Stream power } \\
\text { index (SPI) }\end{array}$ & $\mathrm{m}$ & $\begin{array}{c}\text { Measurement of erosive power connected to } \\
\text { flowing water in a certain catchment area }\end{array}$ \\
\hline $\begin{array}{l}\text { Topographic wet } \\
\text { index (TWI) }\end{array}$ & $\mathrm{m}$ & $\begin{array}{l}\text { Upslope contributing area per width orthogonal to local topographic gradient as a } \\
\text { steady state wetness index (frequently used to analyze soil moisture conditions in a } \\
\text { certain catchment area) }\end{array}$ \\
\hline
\end{tabular}


Table A1. Cont.

\begin{tabular}{|c|c|c|}
\hline Geology & Unit & Explanation \\
\hline Ground layer & - & $\begin{array}{c}\text { Various types of underlying rock or soil after constructing such assoil, } \\
\text { weathered rock and blasted rock }\end{array}$ \\
\hline Rock type & - & Various types of rock such as granite, gneiss and sandstone \\
\hline Joint condition & - & $\begin{array}{l}\text { Condition of discontinuities measured from roughness, } \\
\text { separation and weathering of joint wall }\end{array}$ \\
\hline Joint orientation & ${ }^{\circ}$ & Dip direction measured with geological compass \\
\hline $\begin{array}{c}\text { Weathering } \\
\text { characteristics }\end{array}$ & - & Weathering peculiarity on the bedrock \\
\hline Weathered condition & - & Weathering degree on the bedrock \\
\hline Tension crack & - & $\begin{array}{l}\text { A discrete rock fracture forming perpendicularly to the } \\
\text { direction of maximum extension }\end{array}$ \\
\hline Seepage water & - & $\begin{array}{l}\text { Sporadic seepage flow when the pores between soils or the hole of a crack in a } \\
\text { bedrock become saturated with water and intersect a restrictive layer }\end{array}$ \\
\hline Climate & Unit & $\begin{array}{ll}\text { Explanation } \\
\end{array}$ \\
\hline Rain intensity & $\mathrm{mm} \mathrm{h}^{-1}$ & Hourly rainfall \\
\hline Daily rainfall & $\mathrm{mm}$ day $^{-1}$ & Rainfall in a day \\
\hline Accumulated rainfall & $\mathrm{mm}$ & Cumulative rainfall in a couple of days \\
\hline Soil physics & Unit & Explanation \\
\hline Porosity & $\%$ & Capacity of air-filled voids in dry soil \\
\hline Bulk density & $\mathrm{g} \mathrm{cm}^{-3}$ & Measurement as the dry weight of soil divided by its volume \\
\hline Gravel contents & $\%$ & Mineral particles larger than $2 \mathrm{~mm}$ in diameter \\
\hline Grain size & $\mathrm{mm}$ & Particle size referring to the diameter of individual soil \\
\hline Soil hardness & $\mathrm{mm}$ & $\begin{array}{l}\text { Physical treatment of soil as a result of trampling or by mechanical equipment. } \\
\text { (soil compaction) }\end{array}$ \\
\hline Water content & $\%$ & Water quantity contained in a soil \\
\hline Soil texture & - & $\begin{array}{l}\text { Systematic arrangement of soils classified into relative ratios of sand, silt, and clay } \\
\text { (soil classification) }\end{array}$ \\
\hline $\begin{array}{l}\text { Permeability } \\
\text { coefficient }\end{array}$ & $\mathrm{m} \mathrm{s}^{-1}$ & $\begin{array}{c}\text { Permeability about how much water in a soil can move though pore fractures } \\
\text { (Darcy's law (Calculation by constant head method using the flux per hour, length of } \\
\text { soil column, and hydraulic head)) }\end{array}$ \\
\hline Tensile strength & $\mathrm{kg} \mathrm{m}^{-2}$ & Maximum stress that a soil can withstand while it is stretched before it breaks \\
\hline Shear strength & $\mathrm{kg} \mathrm{m}^{-2}$ & Maximum resistance of a structural member or material to shearing stress \\
\hline Specific gravity & $\%$ & Ratio of the density of a soil \\
\hline Soil chemistry & Unit & Explanation \\
\hline Soil acidity $(\mathrm{pH})$ & - & Soil alkalinity (1:5 solution of soil : water) \\
\hline $\begin{array}{l}\text { Cation Exchange } \\
\text { Capacity (CEC) }\end{array}$ & $\mathrm{cmol} \mathrm{kg}^{-1}$ & The number of positive cations that a soil can hold \\
\hline $\begin{array}{c}\text { Electronic } \\
\text { conductivity (EC) }\end{array}$ & $\mathrm{dS} \mathrm{kg} \mathrm{kg}^{-1}$ & $\begin{array}{l}\text { Measuring ability of a soil to accommodate the transport of an electrical charge. } \\
\text { (generally charged according to the degree of salination) }\end{array}$ \\
\hline Dissolved phosphate & $\mathrm{mg} / \mathrm{kg}$ & Amount guaranteed on the fertilizer label to be available to plants $\left(\mathrm{P}_{2} \mathrm{O}_{5}\right)$ \\
\hline Soil organic matter & $\%$ & Organic components by the decomposed plant and animal residues \\
\hline $\mathrm{C} / \mathrm{N}$ & $\%$ & $\begin{array}{l}\text { Carbon-to-nitrogen ratio (A ratio of the amount of carbon to the amount of nitrogen } \\
\text { in a soil) }\end{array}$ \\
\hline Salt concentration & $\%$ & Soil salinity \\
\hline T-N & $\%$ & Total nitrogen \\
\hline $\begin{array}{l}\text { Exchangeable calcium } \\
\text { (Ca) }\end{array}$ & $\mathrm{cmol} \mathrm{kg}^{-1}$ & Solubility of Ca sources \\
\hline $\begin{array}{l}\text { Exchangeable } \\
\text { magnesium }(\mathrm{Mg})\end{array}$ & $\mathrm{cmol} \mathrm{kg}^{-1}$ & Solubility of $\mathrm{Mg}$ sources \\
\hline $\begin{array}{l}\text { Exchangeable } \\
\text { potassium }(\mathrm{K})\end{array}$ & $\mathrm{cmol} \mathrm{kg}^{-1}$ & Solubility K sources \\
\hline $\begin{array}{l}\text { Exchangeable sodium } \\
(\mathrm{Na})\end{array}$ & $\mathrm{cmol} \mathrm{kg}^{-1}$ & Solubility Na sources \\
\hline Vegetation & Unit & Explanation \\
\hline Forest stand & $\mathrm{m}$ & Large area of predominant trees \\
\hline Tree height & $\mathrm{m}$ & Height of a tree \\
\hline Species diversity & No. & The number of different species that are represented in a certain community \\
\hline $\begin{array}{l}\text { Dominant plant } \\
\text { species }\end{array}$ & No. & $\begin{array}{l}\text { A plant group including the most number and the highest coverage of an individual } \\
\text { plant in a specific ecosystem }\end{array}$ \\
\hline Number of trees & No. & Number of tree species by plant nomenclature \\
\hline Number of herbs & No. & Number of herb species by plant nomenclature \\
\hline Vegetation coverage & $\%$ & Rate of a vegetation area covered in a specific area \\
\hline
\end{tabular}


Table A1. Cont.

\begin{tabular}{|c|c|c|}
\hline Vegetation & Unit & Explanation \\
\hline Vegetation density & No. & The number of different plants that are represented in plant community \\
\hline $\begin{array}{l}\text { Germination } \\
\text { percentage }\end{array}$ & $\%$ & A percentage of germination in a certain amount of time \\
\hline Plant community & - & $\begin{array}{c}\text { A group of plant species expressed by a layered form which classified into tree, } \\
\text { shrub and herbaceous layer in a defined plant area }\end{array}$ \\
\hline Timber age class & No. & An average age of a plant group \\
\hline Timber diameter class & No. & An average diameter of a plant group \\
\hline Root reinforcement & m year $^{-1}$ & Permanently increment in volume of a root or root system \\
\hline Construction & Unit & Explanation \\
\hline Soil depth & $\mathrm{m}$ & Depth of revegetated soil removed from the slope surface down to the ground layer \\
\hline Land use & - & Utilization of use including category designated on developing plans \\
\hline Drainage system & - & $\begin{array}{l}\text { Supporting well-managed drainage system followed by an act, regulation, or } \\
\text { notification of drain facilities provided by the government }\end{array}$ \\
\hline Elapsed year & year & Number of years elapsed since revegetation work was completed \\
\hline Scale of failure & $\mathrm{m}^{2}$ & Damaged slope area when failed \\
\hline Collapse history & - & Previous trace of failure \\
\hline $\begin{array}{l}\text { Reinforced facility for } \\
\text { slope protection }\end{array}$ & - & $\begin{array}{l}\text { Physically-based secondary device to prevent a revegetation measure from failure } \\
\text { when a slope is steep ( } 45^{\circ} \text { or more) and ground layer is weathered rock or blasted } \\
\text { rock (Its method: fiber mesh, wire mesh and gabion block) }\end{array}$ \\
\hline
\end{tabular}

\section{References}

1. Matesanz, S.; Valladares, F.; Tena, D.; Costa-Tenorio, M.; Bote, D. Early dynamics of plant communities on revegetated motorway slopes from southern Spain: Is hydroseeding always needed? Restor. Ecol. 2006, 14, 297-307. [CrossRef]

2. Sheldon, J.C.; Bradshaw, A.D. The development of a hydraulic seeding technique for unstable sand slopes: I. Effects of fertilizers, mulches and stabilizers. J. Appl. Ecol. 1977, 14, 905-918. [CrossRef]

3. Tormo, J.; Bochet, E.; García-Fayos, P. Roadfill revegetation in semiarid mediterranean environments-Part II: Topsoiling, species selection, and hydroseeding. Restor. Ecol. 2007, 15, 97-102. [CrossRef]

4. Morgan, R.P.C.; Rickson, R.J. Slope Stabilization and Erosion Control: A Bioengineering Approach; Taylor \& Francis: New York, NY, USA, 2003.

5. Mitchley, J.; Buckley, G.P.; Helliwell, D.R. Vegetation establishment on chalk marl spoil: The role of nurse grass species and fertiliser application. J. Veg. Sci. 1996, 7, 543-548. [CrossRef]

6. Cerdà, A.; García-Fayos, P. The influence of slope angle on sediment, water and seed losses on badland landscapes. Geomorphology 1997, 18, 77-90. [CrossRef]

7. García-Fayos, P.; Cerdà, A. Seed losses by surface wash in degraded Mediterranean environments. Catena 1997, 29, 73-83. [CrossRef]

8. Kang, G.-C.; Song, Y.-S.; Kim, T.-H. Behavior and stability of a large-scale cut slope considering reinforcement stages. Landslides 2009, 6, 263-272. [CrossRef]

9. Pulko, B.; Majes, B.; Mikoš, M. Reinforced concrete shafts for the structural mitigation of large deep-seated landslides: An experience from the Macesnik and the Slano blato landslides (Slovenia). Landslides 2012, 11, 81-91. [CrossRef]

10. Richards, K.S. Slope Stability; Volume 648, Anderson, M.G., Ed.; John Wiley \& Sons: New York, NY, USA, 1987.

11. Cheng, Y.M.; Lansivaara, T.; Wei, W.B. Two-dimensional slope stability analysis by limit equilibrium and strength reduction methods. Comput. Geotech. 2007, 34, 137-150. [CrossRef]

12. Peng, W.X.; Mo, J.J.; Xie, Y.J. Comparison for the results from 2D and 3D analysis for slope stability. Appl. Mech. Mater. 2011, 90, 255-259. [CrossRef]

13. May, C.L.; Gresswell, R.E. Spatial and temporal patterns of debris-flow deposition in the Oregon Coast Range, USA. Geomorphology 2004, 57, 135-149. [CrossRef]

14. Mikoš, M.; Četina, M.; Brilly, M. Hydrologic conditions responsible for triggering the Stože landslide, Slovenia. Eng. Geol. 2004, 73, 193-213. [CrossRef] 
15. Tecca, P.R.; Galgaro, A.; Genevois, R.; Deganutti, A.M. Development of a remotely controlled debris flow monitoring system in the Dolomites (Acquabona, Italy). Hydrol. Process. 2003, 17, 1771-1784. [CrossRef]

16. Coe, J.; Kinner, D.; Godt, J.W. Initiation conditions for debris flows generated by runoff at Chalk Cliffs, central Colorado. Geomorphology 2008, 96, 270-297. [CrossRef]

17. Godt, J.W.; Coe, J.A. Alpine debris flows triggered by a 28 July 1999 thunderstorm in the central Front Range, Colorado. Geomorphology 2007, 84, 80-97. [CrossRef]

18. Pelfini, M.; Santilli, M. Frequency of debris flows and their relation with precipitation: A case study in the Central Alps, Italy. Geomorphology 2008, 101, 721-730. [CrossRef]

19. Wen, B.P.; Aydin, A. Mechanism of a rainfall-induced slide-debris flow: Constraints from microstructure of its slip zone. Eng. Geol. 2005, 78, 69-88. [CrossRef]

20. Iverson, R.M.; Reid, M.E. Gravity-driven groundwater flow and slope failure potential: $1 . \quad$ Elastic effective-stress model. Water Resour. Res. 1992, 28, 925-938. [CrossRef]

21. Pack, R.T.; Tarboton, D.G.; Goodwin, C.N. The SINMAP approach to terrain stability mapping. In Proceedings of the 8th congress of the international association of engineering geology, Vancouver, British Columbia, Canada, 21-25 September 1998; p. 8.

22. Wu, W.; Sidle, R.C. A distributed slope stability model for steep forested basins. Water Resour. Res. 1995, 31, 2097-2110. [CrossRef]

23. Burton, A.; Bathurst, J.C. Physically based modeling of shallow landslide sediment yield at a catchment scale. Environ. Geol. 1998, 35, 89-99. [CrossRef]

24. Karim, M.N.; Mallik, A.U. Roadside revegetation by native plants I. roadside microhabitats, floristic zonation and species traits. Ecol. Eng. 2008, 32, 222-237. [CrossRef]

25. Mola, I.; Jiménez, M.D.; Jiménez, N.L.; Casado, M.A.; Balaguer, L. Roadside reclamation outside the revegetation season: Management options under schedule pressure. Restor. Ecol. 2011, 19, 83-92. [CrossRef]

26. Bonano, E.J.; Apostolakis, G.E.; Salter, P.F.; Ghassemi, A.; Jennings, S. Application of risk assessment and decision analysis to the evaluation, ranking and selection of environmental remediation alternatives. J. Hazard Mater. 2000, 71, 35-57. [CrossRef]

27. Lee, G.K.L.; Chan, E.H.W. The Analytic Hierarchy Process (AHP) approach for assessment of urban renewal proposals. Soc. Indic. Res. 2008, 89, 155-168. [CrossRef]

28. De Montis, A.; Toro, D.; Droste-franke, B.; Omann, I.; Stagl, S. Criteria for quality assessment of MCDA methods. In Proceedings of the 3rd Biennial Conference of the European Society for Ecological Economics, ESEE, Vienna, Austria, 3-6 May 2000.

29. Altuzarra, A.; Moreno-Jiménez, J.M.; Salvador, M. A Bayesian priorization procedure for AHP-group decision making. Eur. J. Oper. Res. 2007, 182, 367-382. [CrossRef]

30. Banai, R. Anthropocentic Problem Solving in Planning and Design, with Analytic Hierarhy Process. J. Archit. Plan. Res. 2005, 22, 107-120.

31. Cheng, E.W.L.; Li, H.; Yu, L. The Analytic Network Process (ANP) approach to location selecion: A shopping mall illustration. Constr. Innov. 2005, 5, 83-97. [CrossRef]

32. De Felice, F.; Petrillo, A.; Autorino, C. Development of a framework for sustainable outsourcing: Analytic Balanced Scorecard Method (A-BSC). Sustainability 2015, 7, 8399-8419. [CrossRef]

33. Laininen, P.; Hämäläinen, R.P. Analyzing AHP-matrices by regression. Eur. J. Oper. Res. 2003, 148, 514-524. [CrossRef]

34. Saaty, T.L. The Analytic Hierarchy Process: Planning, Priority Setting, Resources Allocation; McGraw-Hill: New York, NY, USA, 1980.

35. Vaidya, O.S.; Kumar, S. Analytic hierarchy process: An overview of applications. Eur. J. Oper. Res. 2006, 169, 1-29. [CrossRef]

36. Rasheed, S.; Wang, C.; Lucena, B. Risk leveling in program environments-A structured approach for program risk management. Sustainability 2015, 7, 5896-5919. [CrossRef]

37. Maerz, N.H.; Youssef, A.; Fennessey, T.W. New risk-consequence rockfall hazard rating system for Missouri highways using digital image analysis. Environ. Eng. Geosci. 2005, 11, 229-249. [CrossRef]

38. Pierson, L.A.; Davis, S.A.; van Vickle, R. Rockfall Hazard Rating System: Implementation Manual; No. FHWA-OR-EG-90-01; Federal Highway Administration U.S. Department of Transportation: Washington, DC, USA, 1990. 
39. Santi, P.M.; Russell, C.P.; Higgins, J.D.; Spriet, J.I. Modification and statistical analysis of the Colorado Rockfall Hazard Rating System. Eng. Geol. 2009, 104, 55-65. [CrossRef]

40. $\mathrm{Xu}, \mathrm{J}$. Analytic hierarchy process for assessing factors influencing the stability of soil slopes reinforced with piles. Environ. Earth Sci. 2013, 70, 1507-1514. [CrossRef]

41. Ayalew, L.; Yamagishi, H.; Ugawa, N. Landslide susceptibility mapping using GIS-based weighted linear combination, the case in Tsugawa area of Agano River, Niigata Prefecture, Japan. Landslides 2004, 1, 73-81. [CrossRef]

42. Gokceoglu, C.; Sonmez, H.; Nefeslioglu, H.; Duman, T.Y.; Can, T. The 17 March 2005 Kuzulu landslide (Sivas, Turkey) and landslide-susceptibility map of its near vicinity. Eng. Geol. 2005, 81, 65-83. [CrossRef]

43. Gray, D.H. Biotechnical and Soil Bioengineering Slope Stabilization: A Practical Guide for Erosion Control; John Wiley \& Sons: New York, NY, USA, 1996.

44. Han, J.G. The characteristics analysis of landslides and rainfall at Pusan area. J. Korea Soc. Environ. Restor. Reveg. Technol. 2001, 4, 24-31. (In Korean).

45. Lee, D.-H.; Yang, Y.-E.; Lin, H.-M. Assessing slope protection methods for weak rock slopes in Southwestern Taiwan. Eng. Geol. 2007, 91, 100-116. [CrossRef]

46. Lee, S.; Ryu, J.-H.; Won, J.-S.; Park, H.-J. Determination and application of the weights for landslide susceptibility mapping using an artificial neural network. Eng. Geol. 2004, 71, 289-302. [CrossRef]

47. Terlien, M.T.J. The determination of statistical and deterministic hydrological landslide-triggering thresholds. Environ. Geol. 1998, 35, 124-130. [CrossRef]

48. Einstein, H.H.; Veneziano, D.; Baecher, G.B.; O’Reilly, K.J. The effect of discontinuity persistence on rock slope stability. Int. J. Rock. Mech. Min. Sci. Geomech. Abstr. 1983, 20, 227-236. [CrossRef]

49. Lu, N.; Godt, J. Infinite slope stability under steady unsaturated seepage conditions. Available online: http:/ / onlinelibrary.wiley.com/doi/10.1029/2008WR006976/full (accessed on 3 August 2015).

50. Yang, X.; Yin, J. Slope Stability Analysis with Nonlinear Failure Criterion. J. Eng. Mech. 2004, 130, $267-273$. [CrossRef]

51. Collins, B.D.; Znidarcic, D. Stability analyses of rainfall induced landslides. J. Geotech. Geoenviron. Eng. 2004, 130, 362-372. [CrossRef]

52. Abramson, L.W. Slope Stability and Stabilization Methods; John Wiley \& Sons: New York, NY, USA, 2002.

53. Chappell, N.; Ternan, J.; Bidin, K. Correlation of physicochemical properties and sub-erosional landforms with aggregate stability variations in a tropical Ultisol disturbed by forestry operations. Soil Tillage Res. 1999, 50, 55-71. [CrossRef]

54. García-Palacios, P.; Soliveres, S.; Maestre, F.T.; Escudero, A.; Castillo-Monroy, A.P.; Valladares, F. Dominant plant species modulate responses to hydroseeding, irrigation and fertilization during the restoration of semiarid motorway slopes. Ecol. Eng. 2010, 36, 1290-1298. [CrossRef]

55. Kil, S.-H.; Lee, D.K.; Cho, M.W.; Yang, B.-E. A study on the factors affecting vegetation cover after slope revegetation. J. Korea. Soc. Environ. Restor. Reveg. Technol. 2011, 14, 127-136. (In Korean).

56. Mosher, D.C.; Moran, K.; Hiscott, R.N. Late Quaternary sediment, sediment mass flow processes and slope stability on the Scotian Slope, Canada. Sedimentology 1994, 41, 1039-1061. [CrossRef]

57. Mukhlisin, M.; Taha, M.R.; Kosugi, K. Numerical analysis of effective soil porosity and soil thickness effects on slope stability at a hillslope of weathered granitic soil formation. Geosci. J. 2008, 12, 401-410. [CrossRef]

58. Osman, N.; Barakbah, S.S. The effect of plant succession on slope stability. Ecol. Eng. 2011, 37, $139-147$. [CrossRef]

59. García-Orenes, F.; Guerrero, C.; Mataix-Solera, J.; Navarro-Pedren, J.; Gómez, I.; Mataix-Beneyto, J. Factors controlling the aggregate stability and bulk density in two different degraded soils amended with biosolids. Soil Tillage Res. 2005, 82, 65-76.

60. Guariguata, M.R. Landslide disturbance and forest regeneration in the upper Luquillo Mountains of Puerto Rico. J. Ecol. 1990, 78, 814-832. [CrossRef]

61. Keim, R.F.; Skaugset, A.E. Modelling effects of forest canopies on slope stability. Hydrol. Process. 2003, 17, 1457-1467. [CrossRef]

62. Watson, A.; Phillips, C.; Marden, M. Root strength, growth, and rates of decay: Root reinforcement changes of two tree species and their contribution to slope stability. Plant Soil 1999, 217, 39-47. [CrossRef]

63. Peterson, D.L.; Silsbee, D.G.; Schmoldt, D.L. A case study of resources management planning with multiple objectives and projects. Environ. Manag. 1994, 18, 729-742. [CrossRef] 
64. Al-Harbi, K.M.A.S. Application of the AHP in project management. Int. J. Proj. Manag. 2001, 19, $19-27$. [CrossRef]

65. Armacost, R.L.; Componation, P.J.; Mullens, M.A.; Swart, W.W. An AHP framework for prioritizing customer requirements in QFD: an industrialized housing application. IIE Trans. 1994, 26, 72-79. [CrossRef]

66. Mawapanga, M.N.; Debertin, D.L. Choosing between alternative farming systems: An application of the analytic hierarchy process. Rev. Agric. Econ. 1996, 18, 385-401. [CrossRef]

67. Huang, R.Y.; Yeh, C.H. Development of an assessment framework for green highway construction. J. Chin. Inst. Eng. 2011, 31, 573-585. [CrossRef]

68. Dale, V.H.; Beyeler, S.C. Challenges in the development and use of ecological indicators. Ecol. Indic. 2001, 1, 3-10. [CrossRef]

69. Locantore, N.W.; Tran, L.T.; O'Neill, R.V.; McKinnis, P.W.; Smith, E.R.; O'Connell, M. An overview of data integration methods for regional assessment. Environ. Monit. Assess. 2004, 94, 249-261. [CrossRef] [PubMed]

70. Huang, L.; Zhang, Z. The Stability of revegetated ecosystems in sandy areas: An assessment and prediction index. Water 2015, 7, 1969-1990. [CrossRef]

71. Saaty, T.L.; Vargas, L.G. Models, Methods, Concepts \& Applications of the Analytic Hierarchy Process; Springer: New York, NY, USA, 2001.

72. Romana, M. New adjustment ratings for application of Bieniawski classification to slopes. In Proceedings of the International Symposium for Rock mechanics, Zacatecas, Mexico, 2-4 September 1985; pp. 49-53.

73. Steinfeld, D.E.; Riley, S.A.; Wilkinson, K.M.; Landis, T.D.; Riley, L.E. Roadside Revegetation: an Integrated Approach to Establishing Native Plant; No. FHWA-WFL/TD-07-005; Federal Highway Administration U.S. Department of Transportation: Washington, DC, USA, 2007.

74. Cano, A.; Navia, R.; Amezaga, I.; Montalvo, J. Local topoclimate effect on short-term cutslope reclamation success. Ecol. Eng. 2002, 18, 489-498. [CrossRef]

75. Rawls, W.J.; Ahuja, L.R.; Brakensiek, D.L.; Shirmohammadi, A.; Maidment, D.R. Infiltration and Soil Water Movement; McGraw-Hill Inc.: New York, NY, USA, 1992.

76. Brady, N.; Weil, R. Elements of the Nature and Properties of Soils, 3rd ed.; Pearson Prentice Hall: Upper Saddle River, NJ, USA, 2009.

77. Lal, R. Soil Quality and Soil Erosion; Soil and Water Conservation Society: Ankeny, IA, USA, 1999.

78. Morgan, R.P.C. Vegetative-based Technologies for Erosion Control. In Eco- and Ground Bio-Engineering: The Use of Vegetation to Improve Slope Stability; Springer: New York, NY, USA, 2007.

79. Toy, T.J.; Foster, G.R.; Renard, K.G. Soil Erosion: Processes, Prediction, Measurement, and Control; John Wiley \& Sons: New York, NY, USA, 2002.

80. Greenwood, J.R. SLIP4EX-A Program for Routine Slope Stability Analysis to Include the Effects of Vegetation, Reinforcement and Hydrological Changes. Geotech. Geol. Eng. 2006, 24, 449-465. [CrossRef]

81. Norris, J.E.; Stokes, A.; Mickovski, S.B.; Cammeraat, E.; van Beek, R.; Nicoll, B.C.; Achim, A. Slope Stability and Erosion Control: Ecotechnological Solutions; Springer: New York, NY, USA, 2008.

82. Osiński, P.; Rickson, R.J.; Hann, M.J.; Koda, E. Assessment of slope stability influenced by vegetation cover and additional loads applied. Ann. Warsaw Univ. Life Sci. Land Reclam. 2014, 46, 81-91.

83. Campbell, G.S.; Norman, J.M. An Introduction to Environmental Biophysics, 2nd ed.; Springer-Verlag: New York, NY, USA, 1998.

84. Evans, T.P.; Winterhalder, B. Modified solar insolation as an agronomic factor in terraced environments. Land Degrad. Dev. 2000, 11, 273-287. [CrossRef]

85. Jeon, G.S. A study on the revegetation structural analysis for environment factor of road slope. J. Korea Soc. Environ. Restor. Reveg. Technol. 2004, 7, 12-20. (In Korean).

86. Korea Highway Corporation (KHC). A Study on Revegetation Method of Cutting-Rock Slopes; Korean Government: Whaseong, Korea, 1999. (In Korean). Available online: http://www.riss.kr/link?id=G3624568 (accessed on 5 January 2016).

87. Tomas, R.; Cuenca, A.; Cano, M.; García-Barba, J. A graphical approach for slope mass rating (SMR). Eng. Geol. 2012, 124, 67-76. [CrossRef]

(C) 2016 by the authors; licensee MDPI, Basel, Switzerland. This article is an open access article distributed under the terms and conditions of the Creative Commons by Attribution (CC-BY) license (http://creativecommons.org/licenses/by/4.0/). 